\title{
Optimization of Two-Stage and Single-Stage Anaerobic Reactors Treating Cheese Whey
}

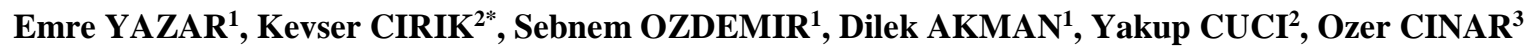 \\ ${ }^{1}$ Kahramanmaras Sutcu Imam University, Department of Bioengineering and Science Kahramanmaras, 46100, \\ Turkey \\ ${ }^{2}$ Kahramanmaras Sutcu Imam University, Department of Environmental Engineering, Kahramanmaras 46100, \\ Turkey \\ ${ }^{3}$ Department of Environmental Engineering, Yildiz Technical University, Istanbul, 34349 Turkey
}

\begin{abstract}
The objective of this research is to compare and evaluate the methane production from cheese whey in single-stage and two-stage anaerobic treatment processes. Single stage-reactor was operated in a pilot-scale batch reactor while two-stage reactor was operated in batch-dilution and semi-continuously. Reactors were loaded with cheese whey with an chemical oxygen demand (COD) of about $38.61 \mathrm{~g} / \mathrm{L}$. Single stage system was operated at $35^{\circ} \mathrm{C}$ with a hydraulic retention time (HRT) of $15,10,7$ and 4 days; respectively. The maximum methane production in the single-stage reactor was obtained at 3.86 gCOD/L.d organic loading rate (OLR) with 10 days HRT being about $0.39 \mathrm{~L} \mathrm{CH}_{4} / \mathrm{L}_{\text {reactor }} / \mathrm{g} \mathrm{COD}_{\text {deg. }} \mathrm{d}$; respectively. The results indicated that the use of a two-stage process for anaerobic treatment of cheese whey resulted in 4 fold higher methane yield compared to single-stage reactor system allowing better control of the acidogenic and methanogenic phases.
\end{abstract}

Keywords: Anaerobic treatment, Biogas, Cheese whey, Hydraulic retention time, Methane production, Phase separation

\section{Peyniraltı Suyu Arıtımında Tek ve Çift Aşamalı Anaerobik Reaktörün Optimizasyonu}

ÖZET: Bu çalışmanın amacı tek ve çift aşamalı anaerobik arıtım proseslerinde peyniraltı suyunda metan üretimini araştırmak ve karşılaştırmaktır. Tek aşamalı reaktör pilot ölçekli kesikli reaktörde işletilirken, çift aşamalı reaktör yarı sürekli ve kesikli olarak işletilmiştir. Reaktör, 38,61g/L kimyasal oksijen ihtiyacına (KOİ) sahip peyniraltı suyu ile yüklenmiştir. Tek aşamalı sistem 15, 10, 7 ve 4 günlük HRT'ler ile $35^{\circ} \mathrm{C}$ 'de işletilmiştir ve maksimum metan üretimi HRT’nin 10 gün olduğu işletme koşulunda 3,86 gKOİ/L.gün seviyelerine ulaşmıştır $\left(0,39 \mathrm{~L} \mathrm{CH}_{4}\right.$ $/ L_{\text {reaktör } / g \text { KOİ }}$ deg.gün). Çalışma sonuçları peyniraltı suyunun anaerobik arıtımında asidojenik ve metanojenik fazların daha iyi kontrol altına alınabildiği iki aşamalı prosesin tek aşamalı prosese göre 4 kat daha fazla metan üretim verimi elde edilebildiğini göstermiştir.

Anahtar Kelimeler: Anaerobik arıtım, Biyogaz, Peyniraltı suyu, Hidrolik bekleme süresi, Metan üretimi, Faz ayrimı

\section{INTRODUCTION}

Cheese whey is a by-product of dairy industry, which is formed after settlement of the casein. This by-product generates about $85-95 \%$ of the milk volume and comprises $55 \%$ of milk nutrients. Cheese whey generally contains lactose, soluble proteins, fats and mineral salts and differs according to the procedure used for casein precipitation $[1,2]$. If the $\mathrm{pH}$ value is lower than 5 , it is called "acidic" cheese whey, as contrary; it's $\mathrm{pH}$ is among 6-7, it is called "sweet" cheese whey [3]. Acidic cheese whey has limited usage due to the high salt concentration and acidity $[4,5]$. Through the production of $1 \mathrm{~kg}$ of cheese, $9 \mathrm{~L}$ cheese whey is formed [6]. Cheese whey production across the globe is 160 million tons [7]. Cheese whey has a value of biological oxygen demand $\left(\mathrm{BOD}_{5}\right)$ between 30-50 g/L and chemical oxygen demand (COD) between $60-80 \mathrm{~g} / \mathrm{L}$. Due to the high organic matter concentrations and limited reuse, much attention has been focused on the effective treatment of acidic cheese whey. Biological methods are commonly considered to be the most effective treatment applications since they present lower operational costs and improved applicability. Anaerobic treatment is the only practical biological method for treating this wastewater, not only reduce the wastewater pollution but also can produce methane gas which is a valuable and renewable energy source. Previous studies have indicated that cheese whey can be effectively used for anaerobic treatment 
[8]. The anaerobic treatment process generally involves two different sets of activities called acidogenesis and methanogenesis; respectively. In the first step (acidogenesis) complex organic matters are converted to simple ones by acid producing bacteria (APB), such as; conversion of lactose into volatile fatty acids (VFAs) which leads a rapid decrease in the $\mathrm{pH}$ of the media. This step relies on fermentation process; and acetate, butyrate, propionate, formic acid, carbon dioxide and hydrogen are among the most known end-products. The biodegradation step mainly occurs in the second step (methanogenesis) in which the end-products of the first step are converted into methane and carbon dioxide by methane producing bacteria (MPB) allowing wastewater to be used for the production of energy in the form of biogas. Conventionally, the first step and the second step of the anaerobic digestion are both performed in a single reactor in which different bacterial groups are to be live together. However, there is often an acidic environment in single-stage anaerobic reactors due to the acid production during acidogenesis phase, which may be inhibitory to MPB. Not only the low $\mathrm{pH}$, but also short HRT may have inhibitory effect on MPB, contrarily; may be favorable conditions to the growth of APB, resulting in insufficient treatment and low methane production yield. Studies have showed the possibility of using two-stage anaerobic reactors by separating acid and methane producing microorganism, thereby; increasing the biogas production efficiency and process stability [9-13]. Two stage reactors allow independently controlling each stage and provide opportunity to optimize growth of APB and MPB.

Conventional anaerobic treatment of cheese whey seems quite problematic due to the tendency to acidify very rapidly. In recent years, several investigators have studied phase separation in anaerobic treatment of cheese whey and many stated that phase separation has increased overall stability, COD removal rate and methane formation [8, 14). The phase separation by using HRT is a good option for slow-growing MPB and fast-growing APB. The primary purpose of this study is to optimize the single and two-stage anaerobic reactors and investigate the phase separation strategy by using HRT. For this aim, single-stage system was operated in pilot scale at a HRT of 15, 10, 7 and 4 days; respectively. Afterwards, separate acidogenic and methanogenic reactors were optimized independently to be able to achieve high methane production yield.

\section{MATERIAL AND METHODS}

\subsection{Process Descriptions and Experimental Set-Up}

Single stage process was performed with a pilot scale batch reactor. The reactor was operated with a volume of $120 \mathrm{~L}$ at $35{ }^{\circ} \mathrm{C}$. Agitation was provided with a motor (Inoxpa, Turino, Italy) and $\mathrm{pH}$ was adjusted to 7.2 with peristaltic pumps (Pentax, Veronella, Italy). The effluent was withdrawn in the middle of the reactor, leaving a working volume of $60 \mathrm{~L}$ at the beginning of the next cycle.

The components of the two-stage process were $1 \mathrm{~L}$ of acidogenic batch reactor and $5 \mathrm{~L}$ of methanogenic batch reactor. The reactors were operated in batch-dilution and semi-continuously (Fig.1). The mixing in the acidogenic reactor was performed by magnetic stirrers and reactor was operated under room temperature $\left(25^{\circ} \mathrm{C}\right)$ with and without $\mathrm{pH}$ control. The methanogenic batch reactor consisted of a 6.5L vessel (Bioflo 110, New Brunswick Scientific Co., Edison, NJ, USA) with an effective working volume of 5L. The contents of the reactor were mixed by a single shaft impeller system at a speed of $150 \mathrm{rpm}$. An internal $\mathrm{pH}$ controller (Bioflo 110 system) was used to control the $\mathrm{pH}$ between 7.2 and 7.3 by adding $0.2 \mathrm{M} \mathrm{HCl}$ and $0.2 \mathrm{M}$ $\mathrm{NaOH}$. The temperature was maintained at $(35 \pm 0.5)^{\circ} \mathrm{C}$. 


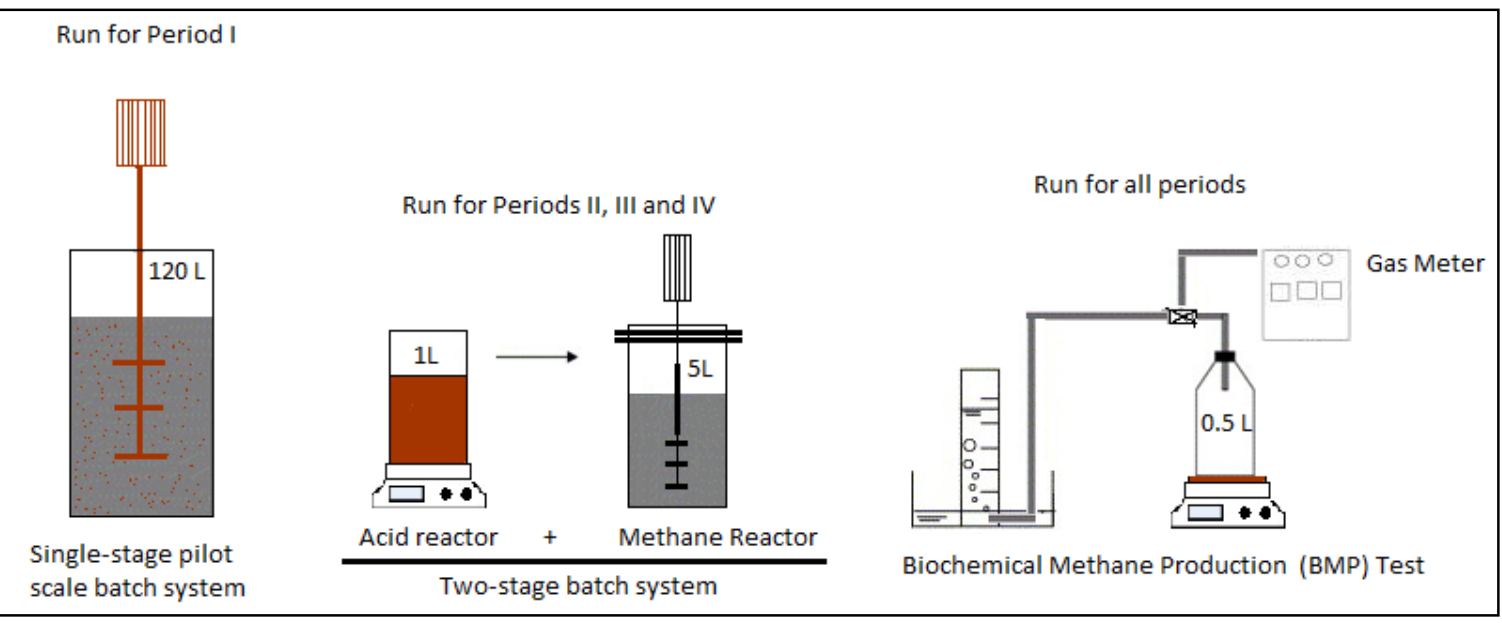

Figure 1. Schematic diagram of the single-stage, two-stage batch reactors and BMP test

BMP testing was done to evaluate gas production rate and methane yield during each study period. Biochemical methane potential (BMP) experiments were run in parallel with single- and two-stage batch systems to accurately measure the produced methane gas (Fig.1). BMP experiments always run in parallel with single and two-stage (for methane reactor) systems and inoculum was renewed each cycle from the continuous reactor. BMP experiments were carried out in duplicates at $35^{\circ} \mathrm{C}$ in $500 \mathrm{ml}$ bottles. Gas production was determined with a glass syringe by the volume displacement technique. The amount of biogas produced and its methane content was measured periodically.

The performance of the single-stage and two-stage reactors was evaluated with over seven different periods (Table 1).

Table 1. Operational conditions

\begin{tabular}{cll}
\hline \multicolumn{2}{c}{ Periods } & Tempe \\
\hline I & Single-stage pilot reactor \\
\hline II & Single-stage pilot reactor \\
\hline III & Single-stage pilot reactor \\
\hline IV & Single-stage pilot reactor \\
\hline V & $\begin{array}{l}\text { Two-stage acid reactor } \\
\text { Two-stage methane reactor }\end{array}$ \\
\hline VI & $\begin{array}{l}\text { Two-stage acid reactor } \\
\text { Two-stage methane reactor }\end{array}$ \\
\hline VII & $\begin{array}{l}\text { Two-stage acid reactor } \\
\text { Two-stage methane reactor }\end{array}$ \\
\hline
\end{tabular}

During Periods I-IV, the effect of HRT on anaerobic treatment of cheese whey in a single-stage reactor was investigated. In this period HRT was decreased from 15 days to 10, 7, 4 days; respectively. In Periods V-VII, two-stage anaerobic process was used to optimize independently acidogenic and methanogenic reactors to be able to achieve high methane production yield. In the Period $\mathrm{V}$, acidogenic reactor was operated with a one day HRT at $25^{\circ} \mathrm{C}$ without $\mathrm{pH}$ control, however; methanogenic reactor was operated with four days HRT at $35^{\circ} \mathrm{C}$ and $\mathrm{pH}$ was adjusted to 7.2. In Period $\mathrm{VI}$, acidogenic reactor was operated with $\mathrm{pH}$ control; methane reactor had the same operational conditions as Period V. In the last Period, the HRT of the methane reactor was increased to 6 days. The operational conditions were changed after observing

\begin{tabular}{|c|c|c|}
\hline erature, ${ }^{\circ} \mathrm{C}$ & pH & HRT, day \\
\hline 35 & 7.2 & 15 \\
\hline 35 & 7.2 & 10 \\
\hline 35 & 7.2 & 7 \\
\hline 35 & 7.2 & 4 \\
\hline 25 & No control & 1 \\
\hline 35 & 7.2 & 4 \\
\hline 25 & 7.0 & 1 \\
\hline 35 & 7.2 & 4 \\
\hline 25 & 7.0 & 1 \\
\hline 35 & 7.2 & 6 \\
\hline
\end{tabular}

considered to be running stable when for at least three days, total organic matter removal, organic acid production, and methane production profiles within a cycle were constant. All assays were run in triplicate and the data illustrated in all figures are the mean values of the measurements for 3 cycles.

\subsection{Cheese Whey and Anaerobic Seed Culture}

Digester sludge from a municipal wastewater treatment plant (Gaziantep Wastewater Treatment Plant, Gaziantep, Turkey) was used as the inoculum. The acid cheese whey was obtained from the AYDA cheese factory (Kahramanmaraş, Turkey). Initially, the pilot scale reactor was started with the addition of 60L of acid whey, followed by inoculation with $720 \mathrm{~g}$ of digester sludge. This 
reactor was operated at $15 \mathrm{~d}$ HRT under batch conditions for 60 days to set up a stable anaerobic culture. After single-stage reactor studies were completed, anaerobic sludge in the pilot scale reactor was used as inoculum for the two-stage anaerobic reactors. Two-stage reactor was operated 15 days to set up a stable acidogenic and methanogenic culture.

Table 2. Composition of raw cheese whey

\begin{tabular}{llc}
\hline Parameter & & Average \pm S.D \\
\cline { 1 - 1 } Alkalinity, (g CaCO & $4.56 \pm 0.1$ \\
Total Organic Carbon, (g/L) & & $1.76 \pm 0.05$ \\
Total Chemical Oxygen & & $38.36 \pm 3.2$ \\
Demand, (g/L) & & \\
Total Nitrogen, (g/L) & & $1.03 \pm 0.82$ \\
Suspended Solids, (g/L) & & $7.9 \pm 0.03$ \\
$\mathrm{NH}_{4}-\mathrm{N},(\mathrm{mg} / \mathrm{L})$ & & $35 \pm 0.03$ \\
$\mathrm{PO}_{4}-\mathrm{P},(\mathrm{mg} / \mathrm{L})$ & & $472 \pm 0.04$ \\
\hline
\end{tabular}

The chemical composition of the cheese whey was presented in Table 2 . The distinctive characteristics are its high organic content and low $\mathrm{pH}$ value.

\subsection{Analyses}

The methane content of the biogas was determined using a portable Cosmos model XP-311 gas meter (Cosmos, Osaka, Japan). The total dissolved organic carbon concentration was determined by a TOC analyzer (Teledyne Tekmar, Torch, USA) equipped with an auto sampler. An ion chromatography (Dionex ICS-3000) was used to measure the concentrations of ions (Dionex, Sunnyvale, CA, USA) with Ion Pac AG19 guard and AS19 analytical columns. Eluent containing $8 \mathrm{mM}$ sodium carbonate $\mathrm{Na}_{2} \mathrm{CO}_{3}$ and $1.5 \mathrm{mM}$ sodium hydroxide $(\mathrm{NaOH})$ was prepared and used for ion analyses with a flow rate of $1 \mathrm{ml} / \mathrm{min}$. Volatile fatty acids (VFAs) were measured by HPLC 3000 liquid chromatography (Thermo Scientific, California, U.S.A.) with OA column at 0.6 mll-1 flow and, with methanesulfonic acid as liquid phase. Alkalinity, $\mathrm{NH}_{4}-\mathrm{N}$, pH, SS and volatile suspended solids (VSS) were determined by standard methods [15].

COD was determined according to APHA standard methods [15]. Samples were acidified with concentrated $\mathrm{H}_{2} \mathrm{SO}_{4}$ to below $\mathrm{pH} 2$ and purged with $\mathrm{N}_{2}$ gas for approximately 5 min to remove $\mathrm{H}_{2} \mathrm{~S}$ prior to COD determination.

\section{RESULTS AND DISCUSSION}

\subsection{Single-Stage Pilot-Scale Reactor Performance \\ 3.1.1. COD Removal}

The operational conditions applied to the single-stage pilot reactor (Period I, II, III and IV) are shown in Table 1 . The temperature and $\mathrm{pH}$ of the system were kept at $35{ }^{\circ} \mathrm{C}$ and 7.2 and only HRT was varied during single-stage reactor studies. COD removal performance and alkalinity production profile of the single-stage reactor is shown in Fig.2.

The COD concentration of influent (raw cheese whey) was about $38.61 \mathrm{~g} / \mathrm{L}$ during all operational conditions. In Period I, single-stage pilot scale reactor was operated at a HRT of $15 \mathrm{~d}$ corresponding to organic loading rate of 2.57 gCOD/L.d. During this During this period, the COD removal in the reactor was at $34 \pm 5 \%$. However, COD removal at the end of the anaerobic period changed as the duration of the period was decreased, being approximately $33 \pm 6 \%$ for the HRT of $10 \mathrm{~d}$ (Period II), 53 $5 \%$ for the HRT of 7d (Period III), and $46 \pm 4 \%$ for the HRT of $4 d$ (Period IV). Some fluctuation was observed during operational conditions. It was observed that after $4 \mathrm{~d}$ of operation the COD value in the reactor started to increase probably due to the release of organic substances (expressed here as COD) as an effect of cell lysis led to a substantial increase in COD except for the 4-day duration. Another reason for this increase might be the solubilisation of particulate matter in the cheese whey. In a study performed by Göblös et al. [8] it was found that decrease in HRT from 40 days to 5 days generally led to a higher COD in the effluent, and COD reduction of between $95-68 \%$ was attained. During the study, the increase of $\mathrm{pH}$ in the reactor was observed as a result of alkalinity generation by the anaerobic biodegradation of organic compounds contained in the cheese whey as depicted in Fig.2. 

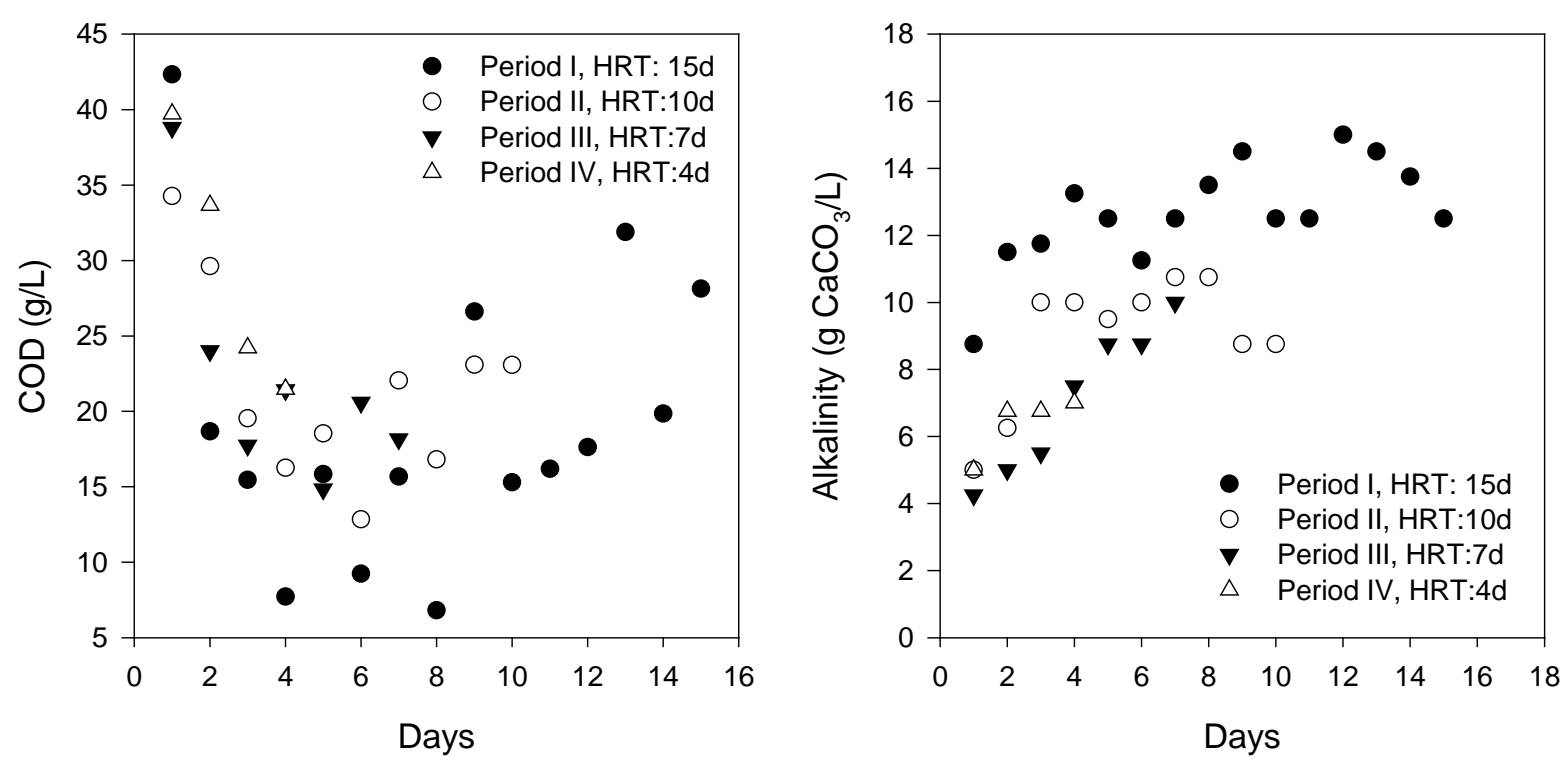

Figure 2. Effect of HRT on COD removal and alkalinity concentrations in single-stage system

The alkalinity production was highest in the Period I (HRT,15d) being about $15 \mathrm{~g} \mathrm{CaCO}_{3} / \mathrm{L}$. In general, methane gas is produced from $\mathrm{H}_{2} / \mathrm{CO}_{2}$ or acetate in the methanogenesis phase in which acetate is a key intermediate metabolite [16]. There are two important pathways involved in methanogenesis; aceticlastic and non-aceticlastic methanogenesis; respectively. If methane is produced by aceticlastic methanogens acetate is converted to $\mathrm{CH}_{4}$ and $\mathrm{CO}_{2}$ and alkalinity is produced. On the other hand; in the non-aceticlastic pathway acetate is first oxidized to $\mathrm{CO}_{2}$ and then the produced $\mathrm{CO}_{2}$ is reduced to $\mathrm{CH}_{4}$ by acetate-oxidizing bacteria and hydrogenotrophic methanogens ( $\mathrm{H}_{2}$-oxidizing); respectively. Tendency of alkalinity raise in the anaerobic reactors give a presumption for the methanogenic pathways. According to our results the alkalinity production observed in the reactor can be explained by both the volatile fatty acids (VFA) converted to $\mathrm{CH}_{4}$ and $\mathrm{CO}_{2}$ by methanogens as well as the alkalinity generated by the anaerobic biodegradation of nitrogeneous organic compound [17].

\subsubsection{Composition of VFAs}

VFAs such as acetate, propionate, butyrate, iso-butyrate, valerate and iso-valerate have long been recognized as the most important intermediates in the anaerobic process in which acetate has been known as a key intermediate metabolite during methanogenesis [18]. The decomposition of VFAs is considered to be the rate-limiting step of the methane production [19]. Therefore, the composition of the VFAs in the biogas reactor under different operational conditions (Period I, II, III, and IV) was also determined and results are shown in Fig.3. The main products of this phase were acetic, propionic and butyric acids, however; valeric and isobutyric acids were not detected.

As seen in Fig.3. acetate was the dominant intermediate metabolite detected in our study except Period I (HRT,15d), in which propionic acid was detected at higher concentrations than acetate. Acetate concentration was the highest in the Period II (HRT, 10d) being about 2000mg/L. It was reported that the accumulation of propionic acid in the anaerobic processes result in low efficiency of the methanogenic phase due to the low acetogenic rate of propionic acid, hence the accumulation of propionic acid is not desired in the anaerobic process [20]. In these experiments the highest concentrations of acetic, butyric and propionic acids reached 1378, 823 and $1153 \mathrm{mg} / \mathrm{L}$, respectively. The single-stage reactor in Period II (HRT, 10d) produced the highest total VFAs. Total organic acids were about 1.7, 2.7, 2.1 and $2.1 \mathrm{~g} / \mathrm{L}$ in Periods I, II, III, and IV; respectively. 

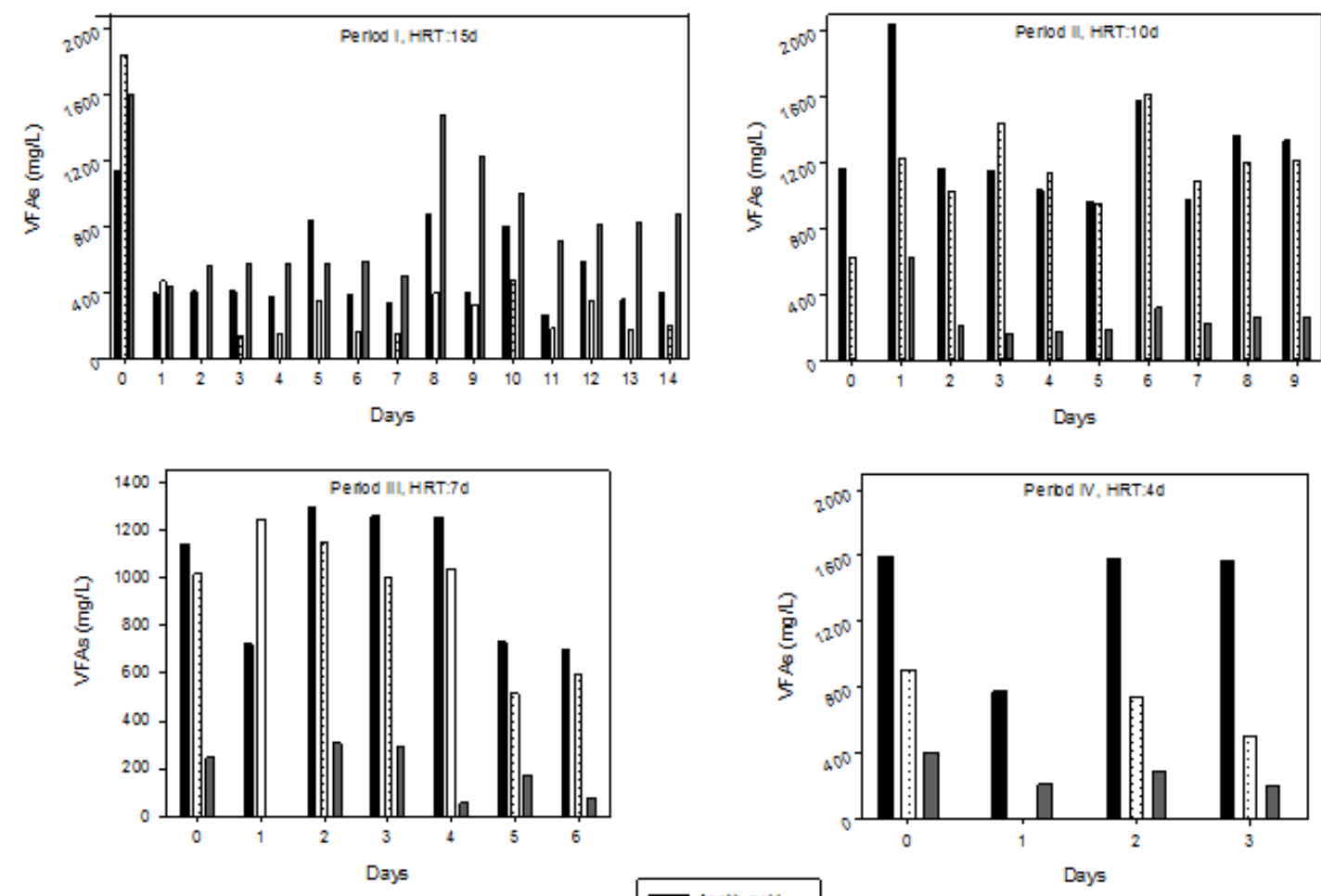

Acetc acld
Butyric act
Proponic acld

Figure 3. Effect of HRT on VFAs composition in single-stage system

\subsection{Two-Stage Reactor Performance}

The aim of this part of the study was to perform an anaerobic system with better running stability and higher working efficiency. Additionally, it was aimed to obtain maximum acidification to enhance methane production in subsequent methanogenic reactor. The operational conditions applied to the two-stage lab-scale reactor (Period V, VI, and VII) are shown in Table 1. The acidogenic reactor was operated at a HRT of one day for all operational conditions without $\mathrm{pH}$ control during Period I, with $\mathrm{pH}$ control (at 7) during Periods VI and VII. The methanogenic reactor was operated at a HRT of $4 \mathrm{~d}$ and $6 \mathrm{~d}$ for Periods V-VI, and VII; respectively.

\subsubsection{COD Removal}

For all operational conditions, the influent COD was almost the same being about $38.61 \mathrm{~g}$ COD/L. Fig.4. represents the COD removals in the two-stage anaerobic reactor under each of the operational conditions.

Acid reactor was inoculated with sludge taken from single-stage anaerobic reactor and operated without $\mathrm{pH}$ control to eliminate the methanogens in the acid reactor since optimum $\mathrm{pH}$ conditions for methanogens (in the range of 6.5-8.2) are at higher values than acidogens. Additionally, the temperature was kept at $25{ }^{\circ} \mathrm{C}$ for all periods since it was known that the number of methanogens decreased significantly with the drop in temperature.

At the start-up period, the HRT was 0.5 day which resulted in washing out of the system as a result of rapid decrease in $\mathrm{pH}$ values resulted from the tendency of cheese whey to acidify rapidly. The observed $\mathrm{pH}$ values in acid reactor were in the range of 2-3.5. It can be concluded that although acidogens are less sensitive to low $\mathrm{pH}$ conditions than methanogens the low $\mathrm{pH}$ values (in the range of 23.5) were not the optimum for acidogenic bacteria. Then, HRT was increased from 0.5 day to one-day. Actually lower HRT values favored the production of VFAs, however; higher values stimulated methanogenic activities, mainly $12 \mathrm{~h}$ was found optimum for VFAs production [21-23]. The system was recovered as a result of increasing HRT to oneday and most of the methanogens were successfully inhibited (no methane was detected during acidogenic stage). The observed $\mathrm{pH}$ values were in the range of 3.5-4.5 in this period. The $\mathrm{pH}$ of acid reactor was increased to 7 for Periods VI and VII after elimination of methanogens under low $\mathrm{pH}$ 
values as acid reactor was more stable at higher $\mathrm{pH}$ values than 3.4-4.5. Actually, $\mathrm{pH}$ is one of the most important factors effecting the organic acid formation in acid reactor [24]. In a study performed by $\mathrm{Yu}$ and Fang [24] $\mathrm{pH}$ was found have a more significant effect on acidogenesis than that of temperature and they observed that optimum $\mathrm{pH}$ for the acidogenic activity is at 6-7. The results corresponding to VFAs production in acid reactor with varying $\mathrm{pH}$ values was introduced in subsequent chapter. Percentage COD removals in the acid reactor and methane reactor are shown in

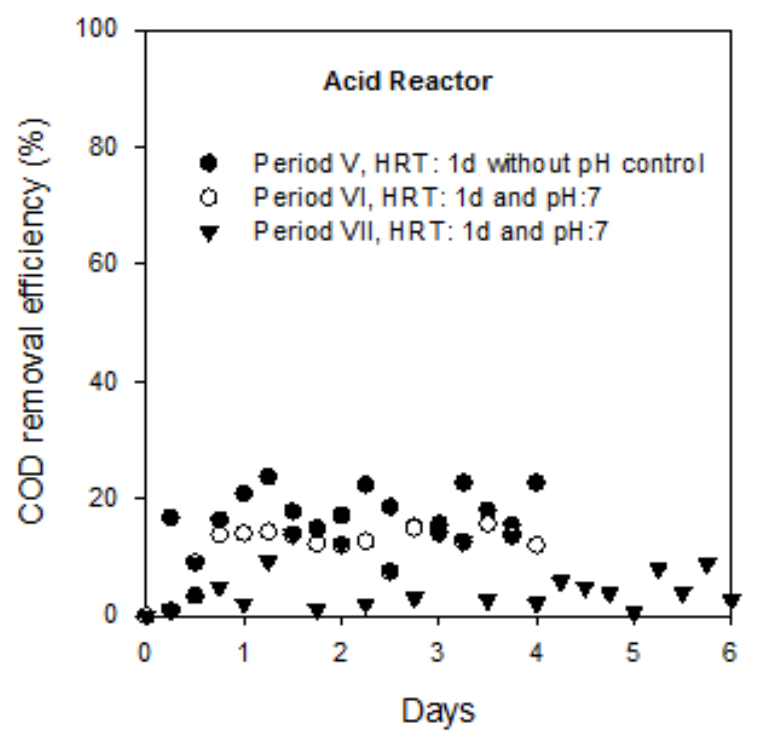

Fig. 4. COD removal during the first step of bioconversion (acid reactor) was 2.5-8.5 g/L, corresponding to a COD removal of about $5-20 \%$. COD removal efficiency in the methane reactor was $74 \%$, 58\%, and 56\% for Periods V, VI, and VII; respectively. As observed in the single-stage studies, a slight increase in COD value was detected for the 6-day duration (Period VII) in methane reactor. The alkalinity was more stable in methane reactor compared to the single-stage pilot reactor and obtained about 9-10 g $\mathrm{CaCO}_{3} / \mathrm{L}$.

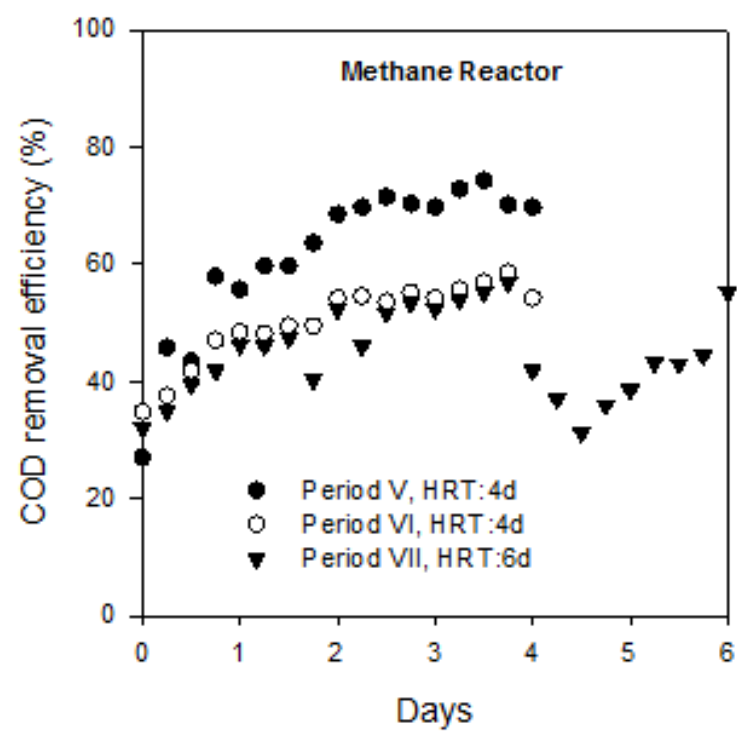

Figure 4. Effect of HRT and $\mathrm{pH}$ control on COD removal efficiency in acid and methane reactor in two-stage system

\subsubsection{Composition of VFAs}

The important products produced in the acidogenesis phase are very important since they can affect the efficiency of the methanogenesis phase [25]. In our study we observed the produced products during acidogenesis phase and the composition of VFAs in acid reactor was represented in Fig. 5. for each operational conditions.

Higher VFAs productions and variety of VFA types were observed with better running stability in acid reactor of two-stage system compared to the sing-stage anaerobic reactor. In these experiments, acetic, butyric and propionic acids were the main VFAs in all of the periods and acetic, butyric and propionic acids reached to the highest concentrations in Period $\mathrm{V}$ (without $\mathrm{pH}$ control, HRT of 1d) being about 1568, 1747, and $2724 \mathrm{mg} / \mathrm{L}$; respectively. The acidogens running without $\mathrm{pH}$ control produced the highest VFAs. Total organic acids were about 4.3, 3.7 and $2.5 \mathrm{~g} / \mathrm{L}$ for Period V, VI, and VII; respectively. It is important to note that the dominant VFA was not acetate in acid reactor of the two-stage system, however; propionic acid concentration was always high compared to the other VFAs in all periods. In the single-stage reactor the concentration of produced total VFAs was $2.7 \mathrm{~g} / \mathrm{L}$ which was lower than those in acid reactor of two-stage system. It has been reported that VFA production depends mainly on wastewater characteristics and operational conditions such as temperature, $\mathrm{pH}$, and HRT [25, 26]. According to our results, the acid reactor can be characterized by its low $\mathrm{pH}$, high VFAs and low COD removal as reported before [12]. Show et al. [27] proposed that the butyric acid/acetic acid ratio is a good indicator of hydrogen yield (not determined in this study), with reported values between 2.1 and 5.9. In our study, acid reactor show higher butyric acid/acetic acid ratios compared to single stage reactor as shown in Fig.5.This proposed the production of $\mathrm{H}_{2}$ during acidogenic stage. 
Determination of the VFA species in the anaerobic treatment is important, since it provides important information regarding the metabolic pathway of the process. The distribution of the metabolic products was different in single and twostage experiments. Partial pressure of hydrogen has a vital role in methane formation and substrate flow. In other words, thermodynamically, the conversion of VFA to methane depends on the partial pressure of the hydrogen (that was hard to measure during our study). Most of the $\mathrm{H}_{2}$ produced comes from oxidation of volatile and long chain fatty acids to acetic acid. Because of the thermodynamics of this reaction, it is inhibited by high partial pressures of $\mathrm{H}_{2}$. $\mathrm{H}_{2}$ production by acetogens is generally energetically unfavorable due to high free energy requirements. An extremely low partial pressure of $\mathrm{H}_{2}\left(10^{-5} \mathrm{~atm}\right)$ known to be a significant factor in propionate degradation to $\mathrm{CH}_{4}$. The partial $\mathrm{H}_{2}$ pressure is normally regulated by $\mathrm{H}_{2}$-consuming (methanogens) and $\mathrm{H}_{2}$ producing bacteria (acetogens). Since methanogens in the acid reactor during the two-stage system operation was washout by $\mathrm{pH}$ regulation, $\mathrm{H}_{2}$ pressure was probably increased since it was not consumed. Therefore, butyric and propionic acid was dominant product during acid reactor. Anaerobic oxidation of propionate by acetogenic bacteria is only possible, if the hydrogen and formate concentrations are kept extremely low [28]. The majority of anaerobic propionate-oxidizing bacteria use the methylmalonyl-CoA pathway, yielding acetate, $\mathrm{CO}_{2}$ and $\mathrm{H}_{2}$, but a second pathway is also possible which leads to butyrate and acetate production [28].

\subsection{Comparison of One-Stage and Two- Stage Reactors in Terms of Methane Production Efficiency}

Fig. 6 illustrates the methane yield and methane productivity profile obtained during one and two-stage configurations operated under different operational conditions. The calculated methane yield was expressed as the liter of methane produced per g of COD degraded per reactor volume per day, while methane productivity was expressed as the liter of methane produced per reactor volume per day. 

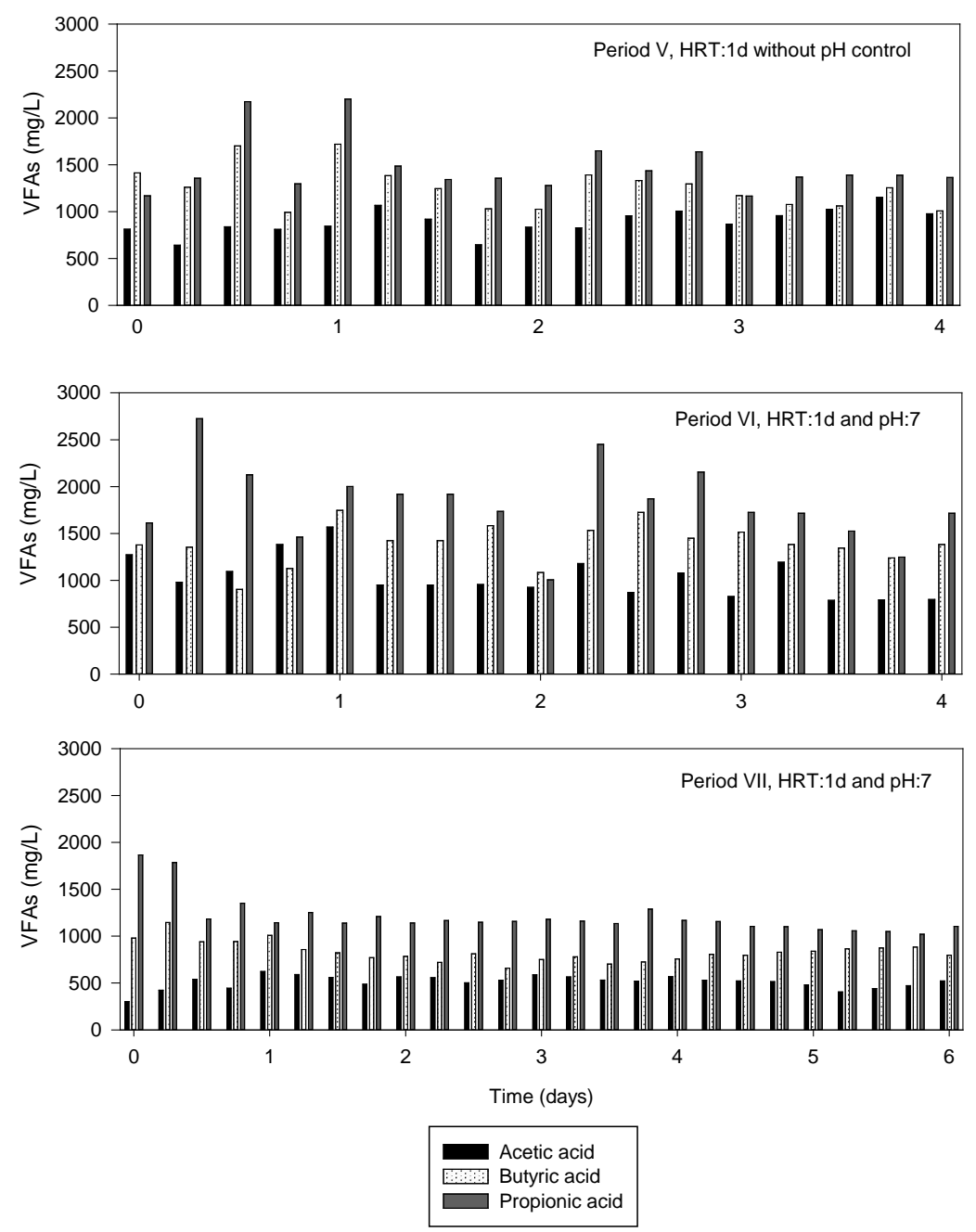

Figure 5. Effect of $\mathrm{pH}$ on VFAs composition in acid reactor in two-stage system

The maximum methane yield in the singlestage reactor system was $0.39 \mathrm{~L} \mathrm{CH} / \mathrm{L}_{\text {reactor }} / \mathrm{g}$ COD $_{\text {deg. }}$.d (Period II; HRT:10d) while it was about $1.56 \mathrm{~L} \mathrm{CH}_{4} / \mathrm{L}_{\text {reactor }} / \mathrm{g} \mathrm{COD}_{\text {deg. }}$.d (Period VI) in twostage reactor system.

Taking into account that theoretically 0.35 $\mathrm{L}$ of methane is produced per gram of COD removed, when assuming that all of the incoming COD is transformed into methane the effectiveness of the anaerobic reactor in converting cheese whey into methane ( $46 \%$ and $28 \%$ of theoretical value for two-stage and single-stage; respectively) at mesophilic temperature is also clearly demonstrated. The maximum methane productivity in the single stage reactor system was $0.5 \quad \mathrm{~L} \mathrm{CH}_{4} / \mathrm{L}_{\text {reactor }} /$ day (Period I; HRT:15d) while it was about $0.8 \mathrm{~L}$ $\mathrm{CH}_{4} / \mathrm{L}_{\text {reactor }} /$ day (Period VI) in two-stage reactor systems. As seen in Fig. 6, methane production in single-stage system increased with the decrease in HRT from 15-day to 10-day, but then start to decrease with decreasing HRT to 7-day and 4-day which can be explained by insufficient duration for biodegradation of readily biodegradable substances. In two-stage system, phase separation was performed by using $\mathrm{HRT}$ and $\mathrm{pH}$.

Acid reactor running with $\mathrm{pH}$ control showed better performance in terms of methane production and increasing HRT from 4-day to 6-day, the methane production was decreased which may be resulted from lower VFAs produced in the previous acid reactor. According to our results; the two-stage process clearly showed a better performance in terms of methane yield which was increased about 4 fold compared to single-stage reactor system allowing better control of the acidogenic and methanogenic phases. However, if the influent organic content is increased, the acidogenic activity, which includes the production of mainly VFA, $\mathrm{CO}_{2}$ and $\mathrm{H}_{2}$, also increases which can result in an accumulation of organic acids and sudden decrease in $\mathrm{pH}$ in the reactor. 
If this practiced in a single-stage reactor, the risk could be bigger since growth of the methane producing methanogens is inhibited below a $\mathrm{pH}$ of 6.6. The time required for organic carbon biodegradation to VFA and further methane is

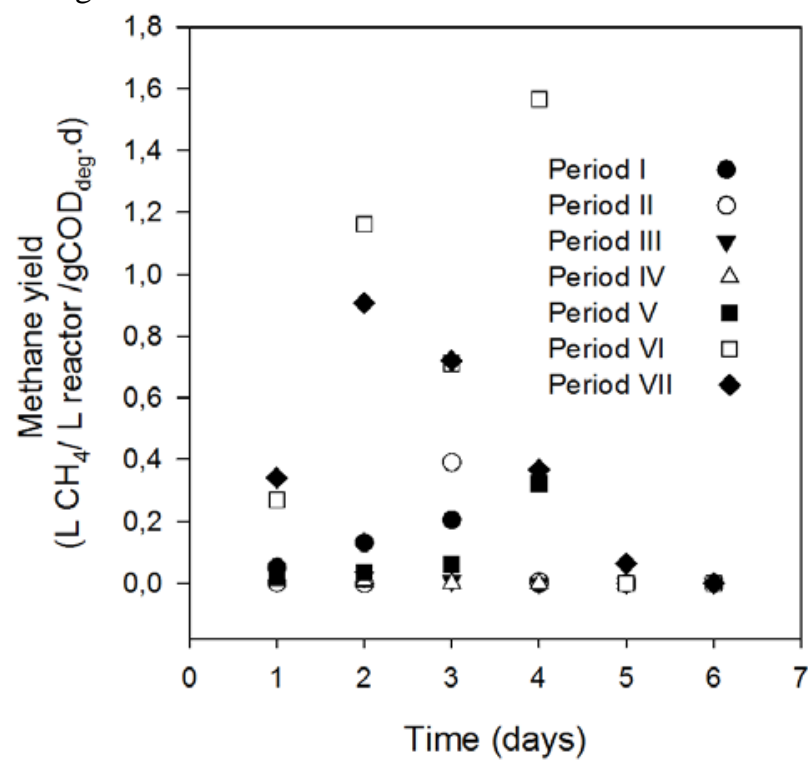

increased, thereby resulting in increasing anaerobic reaction time. Determining the correct HRT is therefore critical to the optimization of reactor performance and maximizing methane production.

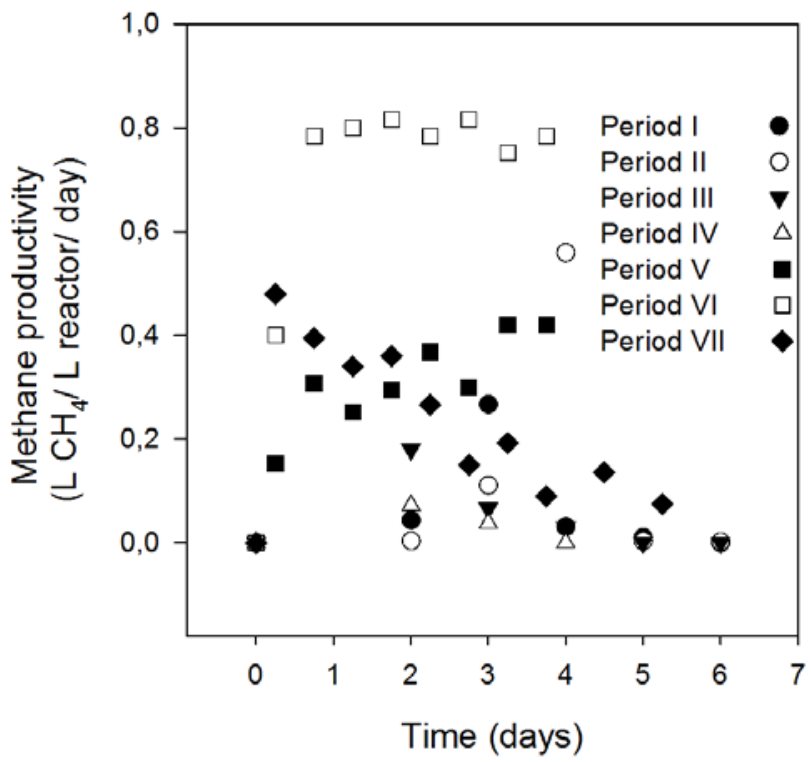

Figure 6. Effect of operational conditions on methane yield and methane productivity in single- and two-stage systems

Ratusznei et al. [29] used a stirred sequencing batch reactor (ASBR) for anaerobic whey treatment. They obtained high organic matter removal of about $96 \%$ at effluent concentration below $160 \mathrm{mg}$ COD/L for non-filtered samples in this single-stage system. In a study performed by Damasceno et al. [30] the effects of feeding time and organic loading in an anaerobic sequencing batch biofilm reactor on whey treatment was investigated. They noted that when filling time was increased from $10 \mathrm{~min}$ to $2 \mathrm{~h}$ and $4 \mathrm{~h}$, volatile acid concentration was increased. Furthermore, no significant differences were detected in the maximum concentration of total volatile fatty acids for any of the conditions investigated. However, the maximum values of propionic acid tended to decrease with increasing fill time considering the same organic load. Additionally, they observed that there was no tendency toward acid accumulation, indicating that $8 \mathrm{~h}$ total cycle time remained insufficient for complete volatile acids consumption. Saddoud et al. [12] studied a system consisting of a stirred acidogenic reactor followed by a methanogenic reactor coupled with a membrane filtration system for the treatment of cheese whey. They achieved biogas methane content higher than $70 \%$ and biogas production 10 times higher than reactor volume. The removals of $\mathrm{COD}$ and $\mathrm{BOD}_{5}$ were higher than 98\%. In another study performed by Yang et al. [31] one and two-phase thermophilic anaerobic digestion systems were used for cheese whey treatment. According to that of study results; rate of COD removal, rate of and yield of methane formation in the two-phase process were, respectively, $116 \%, 43 \%$, and $6 \%$ higher than those of the single-phase system were.

\section{CONCLUSION}

In this study single-stage and two-stage anaerobic treatment of cheese whey was performed and effect of HRT was investigated in single-stage reactor. HRT of 10d was found optimum in terms of percentage COD removal (33\%), biogas production yield (0.39 $\mathrm{L} \mathrm{CH}_{4} / \mathrm{L}_{\text {reactor }} / \mathrm{g} \mathrm{COD}_{\text {deg.d) }}$ ) and biogas productivity ( $0.5 \mathrm{~L} \mathrm{CH}_{4} / \mathrm{L}_{\text {reactor }} /$ day). Total VFA concentration of $2.7 \mathrm{~g} / \mathrm{L}$ was obtained. In two-stage reactor system, a maximum TVFA concentration of $4.3 \mathrm{~g} / \mathrm{L}$ was achieved in the acid reactor at an HRT of $1 \mathrm{~d}$ without $\mathrm{pH}$ control. Two-stage reactor system led to an increase of TVFA production about 1.5 fold compared to single stage reactor system. The low COD removals were attained in acid reactor between $5-20 \%$ for all operational conditions. COD removal efficiency was $53 \%$ in single-phase system, which was increased to $\% 74$ in methane reactor of two-stage system. 4-day duration of methane reactor was found optimum for this study for effective COD removal and methane production. The methane 
production efficiency is mostly dependent on acetate availability that can be optimized in acid reactor. The higher acetate production in acid reactor resulted in higher methane production in methane reactor. The two-stage process clearly showed a better performance in terms of methane yield, which was increased about 4 fold, compared to single stage reactor system.

\section{ACKNOWLEDGMENT}

This research was supported by Kahramanmaras Sutcu Imam University, Division of Scientific Research Projects, through grant 2011/48YLS. The authors are thankful to the anonymous reviewers for their insightful comments and suggestions.

\section{REFERENCES}

[1]. Wit JN de (2001). Lecturer's Handbook on whey and whey products. European Whey Products Association (EWPA) 14, Rue Montoyer1000 Brussels, Belgium.

[2]. Farizoglu B, Keskinler B, Yildiz E, Nuhoglu A (2004). Cheese whey treatment performance of an aerobic jet loop membrane bioreactor. Process Biochemistry, 39:2283-2291.

[3]. Siso GMI (1996). The biotechnological utilization of cheese whey: A review. Bioresour Technol, 57:1-11.

[4]. Panesar PS, Kennedy JF, Gandhi DN. Bunko K (2007). Bioutilisation of whey for lactic acid production. Food Chemistry, 105: 1-14.

[5]. Prazeres AR, Carvalho F, Rivas J (2012). Cheese whey management: A review. Journal of Environmental Management, 110:48-68.

[6]. Atamer Z, Samtlebe M, Neve H, Heller KJ, Hinrichs J (2013). Review: Elimination of bacteriophages in whey and whey products. Frontiers in Microbiology, 4:1-9.

[7]. Smithers GW (2008). Whey and whey proteins-from 'gutter-to-gold'. Int Dairy J, 18:695-704.

[8]. Göblös Sz, Portörő P, Bordás D, Kálmán M, Kiss I (2008). Comparison of the effectivities of two-phase and single-phase anaerobic sequencing batch reactors during dairy wastewater treatment. Renew Energy, 33:960-965.

[9]. Wang Z, Banks CJ (2003). Evaluation of a two stage anaerobic digester for the treatment of mixed abattoir wastes. Process Biochem, 38:1267-1273.

[10]. Demirer G, Chen S (2005). Two-phase anaerobic digestion of dairy manure. Process Biochem., 40(11):3542-3549.

[11]. Ke S, Shi Z (2005). Applications of twophase anaerobic degradation in industrial wastewater treatment. Int $\mathrm{J}$ Environ Pollut, 23:65-80.
[12]. Saddoud A, Hassari I, Sayadi S (2007). Anaerobic membrane reactor with phase separation for the treatment of cheese whey. Bioresour Technol, 98:2102-2108.

[13]. Cui F, Lee S, Kim M (2011). Removal of organics and nutrients from food wastewater using combined thermophilic two-phase anaerobic digestion and shortcut biological nitrogen removal. Water Res, 45:5279 -5286.

[14]. Guerrero L, Montalvo S, Coronado E, Chamy R, Poirrier P, Crutchik D, Sánchez E, De La Rubia MA, Borja R (2009). Performance evaluation of a twophase anaerobic digestion process of synthetic domestic wastewater at ambient temperature. J Environ. Sci Health A Tox Hazard Subst Environ Eng, 44(7):673681.

[15]. APHA, 2005. Standard Methods for the Examination of Water and Wastewater. American Public Health Association/American Water Works Association/Water Environment Federation, Washington D.C.

[16]. McCarty PL (1981). One hundred years of anaerobic digestion, anaerobic digestion, Amsterdam: Elsevier Biochemical Press BV pp: 3-22.

[17]. Wen Z, Liao W, Chen S (2004). Hydrolysis of animal manure lignocellulosics for reducing sugar production. Biores Technol, 91(1):31-9.

[18]. Mechichi T, Sayadi S (2005). Evaluating process imbalance of anaerobic digestion of olive mill wastewaters. Process Biochem, 40:139-145.

[19]. Ueno Y, Sasaki D, Fukui H, Haruta S, Ishii M, Igarashi Y (2006). Changes in bacterial community during fermentative hydrogen and acid production from organic waste by thermophilic anaerobic microflora. J Appl Microbiol, 101:331343. 
[20]. Wang L, Zhou Q, Li FT (2006). Avoiding propionic acid accumulation in the anaerobic process for biohydrogen production. Biomass and Bioenergy, 30:177-182.

[21]. Zoetemeyer RJ, van den Heuvel JC, Cohen A (1982). pH influence on acidogenic dissimilation of glucose in an anaerobic digester. Water Res, 16:303311.

[22]. Sans C, Mata-Alavarez J (1995). Acidogenic fermentation of organic urban wastes in a plug-flow reactor under thermophilic conditions. Bioresour Technol, 54:105-110.

[23]. Kim JQ, Somiya I, Shin EB, Bae W, Kim SK, Kim RH (2002). Application of membrane-coupled anaerobic volatile fatty acid fermentor for dissolved organics recovery from coagulated raw sludge. Water Sci Technol, 45(12):167174.

[24]. Yu HQ, Fang HP (2003). Acidogenesis of gelatin-rich wastewater in an upflow anaerobic reactor: Influence of $\mathrm{pH}$ and temperature. Water Res, 37:55-66.

[25]. Wang Y, Zhang Y, Wang J, Meng L (2009). Effects of volatile fatty acid concentrations on methane yield and methanogenic bacteria. Biomass and Bioenergy, 33:848-853.

[26]. Sentürk E, İnce $M$, Onkal Engin G (2010). Treatment efficiency and VFA composition of a thermophilic anaerobic contact reactor treating food industry wastewater. J Hazard Mater, 176:843848.

[27]. Show KY, Zhang ZP, Tay JT, Liang DT, Lee DJ, Jiang WJ (2007). Production of hydrogen in a granular sludgebased anaerobic continuous stirred tank reactor. Int J Hydrogen Energy, 32 (18):47444753.

[28]. de Bok FAM, Plugge CM, Stams AJM (2004). Interspecies electron transfer in methanogenic propionate degrading consortia. Water Res, 38:1368-1375.

[29]. Ratusznei SM, Rodrigues JAD, Zaiat M (2003). Operating feasibility of anaerobic whey treatment in a stirred sequencing batch reactor containing immobilized biomass. Water Sci Technol, 48:179-186.

[30]. Damasceno LHS, Rodrigues JAD, Ratusznei SM, Zaiat M, Foresti E (2007). Effects of feeding time and organic loading in an anaerobic sequencing batch biofilm reactor (ASBBR) treating diluted whey. J Environ Manag, 85:927-935.

[31]. Yang K, Yu Y, Hwang S (2003). Selective optimization in thermophilic acidogenesis of cheese-whey wastewater to acetic and butyric acids: partial acidification and methanation. Water Res, 37:2467-2477. 